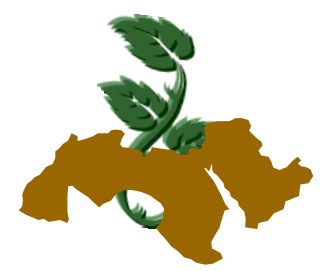

Arab Univ.

J. Agric. Sci.,

Ain Shams Univ.,

Cairo, 19(1), 233-244, 2011

\title{
ROLE OF POTASSIUM AND SALINITY EFFECTS ON GROWTH AND CHEM- ICAL COMPOSITIONS OF DATE PALM PLANTLETS
}

\author{
Darwesh, Rasmia ${ }^{1}$, S.S. and A.A. El-Banna ${ }^{1}$ \\ 1- Central Laboratory for Research and Development of Date palm, Agriculture Research Cen- \\ ter, Giza, Egypt
}

Keywords: Potassium, Salinity, Proline, Date palm

\section{ABSTRACT}

A greenhouse pot experiment was carried out to investigate the effect of salinity and potassium at different levels alone or in various combinations on growth, mineral and proline content in leaves of plantlets of Phoenix dactylifera L. cv. Bartomouda (in vitro production, two years old from acclimatized them). The following treatments were applied: three levels of salinity $\mathrm{Na} \mathrm{Cl}+\mathrm{Ca} \mathrm{Cl}_{2}$ w.w 2:1 (14000, 16000 and 18000 ppm.) and two levels of potassium (2000 and 3000 ppm) in addition to control (no salts or potassium used), salts and potassium were added in the irrigation water. In general, all levels of salinity significantly decreased various growth parameters such as plant height, number of leaves and roots, root length, fresh and dry weights of leaves than that of the control. These parameters were decreased with increasing salinity levels, whereas it, significantly increased $\mathrm{Na}$, $\mathrm{Ca}$ and $\mathrm{K}$ contents in leaves with high content of proline. The treatment 18000 ppm salts gave the highest significant reduction of the growth parameters, while caused an increase in proline $\mathrm{Na}, \mathrm{Ca}$, and $\mathrm{K}$ contents compared to control treatment (no salts) . This was true in both seasons. The applications of potassium significantly increased the previous growth parameters as compared with the control treatment (without salts and potassium) the treatment $3000 \mathrm{ppm}$ had the highest results. Moreover the applications of potassium gave high alleviated the negative effects of salt stress, the treatment $3000 \mathrm{ppm}$ gave the best results on the growth parameters of date palm plantlets grown under salinity condition. Regarding the interaction the obtained data revealed that the interaction between treatment $3000 \mathrm{ppm}$ potassium and 14000 salts produced the highest significant results. Gen- erally, from the obtained results it can conclude that the plantlets of date palm produced by tissue culture can be tolerated salt stress by addition of potassium which can significantly ameliorate the harmful effects of salts, positive effects on the growth parameters of the plantlets was showed by potassium applications.

\section{INTRODUCTION}

Date palm is considered a salt tolerance plant species, but the information of salt tolerance among the cultivars was very limited Al- Mansoori et al (2007). Increasing of salinity levels $(\mathrm{NaCl})$ led to significant decreases in growth parameters, ElTantawy et al (2006) on Phoenix dactylifera L. Mahdavi and Sanavy (2007) on Lathyrus sativus, El-Araby et al (2008) on Tomato, Khalid et al (2008) on Cicer arietinum L.)). Leaf content of $\mathrm{Na}$, $\mathrm{Ca}$ and $\mathrm{K}$ was increased with increasing of salinity levels Subbarao et al (2003) and Mahmoud and Athar (2008) on Panicum turgidum, Naeem et al (2006) on Wheat, Tsialtas and Maslaris (2006) on sugar beets, Sortiropoulos et al (2006) on pear rootstocks and Mickelbart et al (2007) on avocado. Proline content took the same trend with salinity levels (Bondok et al (1995) on peach, Wan et al (2006) and Sannazzaro et al (2007) on Lotus glaber. The applications of potassium significantly increased the previously growth parameters and leaf mineral content and proline. Moreover Sorial et al (2001) on (Mentha piperita) peppermint, Delgado and Sanchez (2007) on sunflower and Kaya et al (2007) on Cucumis melo found that addition of potassium significantly ameliorated the adverse effects of salinity. This experiment aims to investigate the effect of potassium applications on growth parameters and leaf mineral content of date palm plantlets (produced by tissue culture) grown under salinity stress. 


\section{MATERIALS and METHODS}

This study was conducted at the Central Laboratory for Research and Development of Date palm, Agriculture Research Center (ARC) Giza, in 2008- 2009, on plantlets of Phoenix dactylifera L. cv. Bartomouda produced by in vitro culture and acclimatized them in the greenhouse in plastic bags that contain sand: peatmoss 2:1 (Ec 3.06 $\mathrm{ds} / \mathrm{cm})$, these plantlets were nearly uniform and relative in size, growth and vigor $(20-30 \mathrm{~cm}$ height, 3-4 leaves, $20-25 \mathrm{~cm}$ for root length and 4-5 roots/plantlet) and used to study the effect of different levels of salinity and potassium $\left(k^{+}\right)$on growth parameters and leaf mineral and proline content. Three levels of salinity 14000, 16000 and $18000 \mathrm{ppm}\left(\mathrm{NaCl}+\mathrm{CaCl}_{2} 2: 1\right.$ w.w) were applied alone or in combination with two levels of potassium 2000 and 3000 ppm (as potassium sulfate), in addition to control treatment. Salts and potassium were added in the irrigation water, three replicates were used for this experiment and three plantlets for each replicate. After six months from treatments the following data for each season were recorded:

1- Plant height $\mathrm{cm}$. and number of leaves/ plantlet

2- Root length $\mathrm{cm}$. and number of roots/plantlet

3- Fresh and dry weights of leaves

4- Proline content in leaves was determined as described by Bates et al (1973) as follows:

\section{$\mathrm{Mg} / \mathrm{g}$ proline $=\mathrm{ppm} . \mathrm{x} \mathrm{ml}$. extract} $2 \times$ g. samples $x 10$

5- $\mathrm{Na}, \mathrm{Ca}$ and $\mathrm{K}$ contents in leaves were determined as described by Jackson (1973).

Results were subjected to analysis of variance using factorial experiments in a completely randomized design and L.S.D. (0.05) was used for comparison (Snedecor and Cochran 1980).

\section{RESULTS AND DISCUSSION}

The potassium cation takes a crucial part in many metabolic processes in the cell, It serves as an osmoregulator and participates in several processes that take care of the water management of plants. Potassium helps to built thicker cell walls, and increases the concentration of electrolytes inside the cell, thus increasing the plant's resistance. Since potassium is one of the most important macro- nutrients in plants, understanding the mechanisms of $\mathrm{K}+$ uptake and transport is es- sential for revealing the controlling steps of plant growth and for improving crop yields even under unfavorable growth conditions such as salinity. For plants growing on saline soils, it is crucial to maintain the Na:K ratio by favoring the accumulation of potassium over sodium

\section{Plant height (cm)}

The results of both seasons (Tables 1 and 2) revealed that all levels of salinity $\left(\mathrm{NaCl}+\mathrm{CaCl}_{2}\right)$ significantly decreased plant height than that of the control. Increasing salinity caused a decrease in plant height. In other words; plant height was decreased as levels of salinity increased. The significant highly reduction of plant height occurred at the treatment of $18000 \mathrm{ppm}$ salts (93.0 and 99.3 $\mathrm{cm}$ respectively for $1^{\text {st }}$ and $2^{\text {nd }}$ seasons as compared with other treatments. Control treatment (no salts used) gave the highest results which produced 120 and $124.6 \mathrm{~cm}$ in $1^{\text {st }}$ and $2^{\text {nd }}$ seasons, respectively. These results are in accordance with those obtained by El- Tantawy et al (2006) on Phoenix dactylifera L, Gherroucha et al (2003) on wheat, Seema and Amar (2008) on Acacia senegal, Khalid et al (2008) on Cicer arietinum plumule, Zaki et al (2009) on sweet fennel cultivars Bhadauria and Kumar (2008) on okra Abelmoschus esculentus L., and Castro et al (2008) on avocado Persea Americana Mill They all reported that salinity levels $(\mathrm{NaCl})$ were decreased plant height and the decrement was indirect proportion with rising levels of salinity.

As for the alleviation effects of potassium on the negative effects of salinity $\left(\mathrm{NaCl}+\mathrm{CaCl}_{2}\right)$, data of (Tables 1 and 2) also show that the applications of potassium stimulated the plant height compared to control treatment (salts only), the treatment 3000 ppm had the highest results of plant height (116.4 and $122.3 \mathrm{~cm}$ in the $1^{\text {st }}$ and $2^{\text {nd }}$ seasons respectively). More significant effective was in the interaction between $3000 \mathrm{ppm}$ of potassium and 14000 ppm salinity $(121.8$ and $127.2 \mathrm{~cm})$ in $1^{\text {st }}$ and $2^{\text {nd }}$ seasons respectively. These results are in accordance with those obtained by, Azza et al (2006) on Dalbergia sissoo, and Bajehbaj (2010) on Helianthus annuus L. Kaya et al (2007) on Cucumis me1o L. they reported that addition of some nutrients such as potassium and sulphur was significantly alleviated the adverse effects which induced by $\mathrm{NaCl}$. 


\section{Number of leaves/plantlet}

Results presented in Tables (1 and 2) reveal the same trends as observed on plant height, i.e. all salinity treatments significantly decreased the number of leaves/plantlet, as compared with the control in both seasons. Meanwhile, clear differences were detected between various levels of salinity and the decrease in number of leaves/ plantlet. The highest significant was reduction by the treatment $18000 \mathrm{ppm}$ which gave 10.0 and 10.3 leaves/plantlet, compared to control treatment which gave the highest significant result (13.0 and 14.0 ) in the $1^{\text {st }}$ and $2^{\text {nd }}$ seasons respectively. These results were similar with, Abdou et al (2006) on sweet fennel, and Kulkarni et al (2007) on Punica granatum L. Musyimi et al (2008) on avocado Al-Hamdani (2008) on puerana lobata L and El-Araby et al (2008) on tomato, and more recently with Muhammad and Hussain (2010) on five medicinal plants (Lepidium sativum L., Linum usitatissimum L., Nigella sativa L., Plantago ovataForssk, and Trigonella foenum-graecum $\mathrm{L}$. They stated that, numbers of leaves of were decreased by levels of $\mathrm{NaCl}$.

In regard to the effect of potassium on number of leaves/plantlet (Table 1 and 2) where salinity stresses was founded. The levels 3000 ppm potassium were produced the best results (13.7 and 14.3 leaves/plantlet) followed by 2000 ppm (11.6 and 12.3 leaves/plantlet) compared to control treatment (9.2 and 10.0 leaves/plantlet), respectively for $1^{\text {st }}$ and $2^{\text {nd }}$ seasons. The obtained data revealed that the interaction between treatment 3000 ppm potassium and 14000 salts were produced the highest significant results. These results are in harmony with those mentioned by Badr et al (2005), Sakr and Arafa (2009) on Brassica napus $\mathrm{L}$, Kaya et al (2007) on Cucumis melo $\mathrm{L}$ found that $48 \mathrm{~kg} / \mathrm{fed}$ as $\mathrm{K}_{2} \mathrm{O}$ or $5 \mathrm{mM}$ to $0.8 \mathrm{~g} /$ pot as potassium sulfate or $5.6 \mathrm{~cm} 3 / \mathrm{l}$ as a foliar application also spermine at $10 \mathrm{mg} / \mathrm{l}$ and ascorbic acid at $200 \mathrm{mg} / \mathrm{l}$ had a stimulating impact and may alleviate the effect on increasing the adverse effects of salinity.

\section{Root length (cm)}

Regarding the effect of salinity on average of root length, results from Table (1 and 2) reveal the same trends as observed in plant length, i.e. all salinity treatments significantly decreased root length than those of the control treatment. This was true in the two seasons of study. A lowest reduction was recorded at level 14000 ppm (30.5 and $31.2 \mathrm{~cm}$ ), meanwhile the $18000 \mathrm{ppm}$ gave the highest inhibition results $(25.2$ and $26.4 \mathrm{~cm}$ in the $1^{\text {st }}$ and $2^{\text {nd }}$ seasons respectively) comparable with the control treatment. Similar results were obtained by Hokmabadi et al (2005) on Pistachio vera L., Kathiresan and Rajendran (2008) on mangarove (Rhizophora apicatata) seedlings, Jampeetong and Brix (2009) on Salvinia natans, and Prakash et al (2010) on cowpea, they all reported that, increasing levels of salinity $(\mathrm{NaCl}$ at 50,100 and 150 $\mathrm{mM}$ ) decreased root length.

In regard to the effect of potassium on root length under salinity conditions results presented in Tables (1 and 2) in both seasons indicated that the studied treatments of potassium mitigated the harmful effects of different levels of salinity $\left(\mathrm{NaCl}+\mathrm{CaCl}_{2}\right)$ on the root length. The significant highest length of roots was noticed at $3000 \mathrm{ppm}$ potassium $\left(33.7\right.$ and $35.3 \mathrm{~cm}$. for $1^{\text {st }}$ and $2^{\text {nd }}$ seasons respectively) with the highest significant interaction with $14000 \mathrm{ppm}$ of salinity compared to control treatment. These data were supported by, Shirazi et al (2005) on wheat who found that, an increase in the shoot and root length had occurred with application of $\mathrm{K}^{+}\left(10 \mathrm{mmol} \mathrm{Kcl} / \mathrm{ds}^{3}\right)$. The enhanced growth of these genotypes under saline condition might be due to the quick response to external $\mathrm{K}^{+}$application. In addition Malakouti (2006) stated that, $K_{+}$application under salinity conditions would improve root expansion and elongation of Pistachio, and also would increase the surface area contact between tree roots and soil nutrients.

\section{Number of roots}

Its shown from Table ( 3 and 4 ) that the significant inhibition effect of all levels of salinity (14000, 16000 and $18000 \mathrm{ppm} \mathrm{NaCl}+\mathrm{CaCl}_{2}$ ) on roots number, the highest depression of roots number (6.6 and 7.5 roots/plantlet) was obtained by the treatment 18000 ppm., while the treatment of $14000 \mathrm{ppm}$ gave the lowest significant reduction of number of roots (8.0 and 9.0 roots/plantlet) compared to control treatment which produced 8.5 and 9.7 roots/plantlet. In this respect, Shibli et al (2003) on Prunus dulcis and Dashtakian and Bahrani (2007) on Rubia tinctorum $L$ stated that, roots number was decreased with rising salinity levels ( $\mathrm{NaCl})$, and Kapoor and Srivastava (2010) elucidated that number of roots of Vigna mungo were reduced by $2.5 \% \mathrm{NaCl}$.

Regarding the effect of potassium on roots number results from Tables (3 and 4 ) proved that the highest significant stimulation effects of potassium on number of roots which was noticed at 
3000 ppm potassium (9.1 and 10.6) followed by 2000 ppm (7.3 and 8.4) compared to control treatment (6.3 and 6.9 roots/plantlet) in the $1^{\text {st }}$ and $2^{\text {nd }}$ seasons, respectively. Highly significant interaction between 3000 ppm of potassium and 14000 ppm of salinity existed which had (9.6 and 10.8 roots/plantlet, in the $1^{\text {st }}$ and $2^{\text {nd }}$ seasons respectively). These data showed that potassium treatments enhanced some root parameters such as expansion and elongation under salinity stress, and then mitigated the harmful effects of salinity on plant growth.

\section{Fresh and dry weights of leaves}

Tables (3 and 4) revealed that exposure of plantlets of date palm to salinity levels at 14000 , 16000 and 18000 ppm salts decreased fresh and dry weights of leaves compared to control treatment. Generally, increasing salinity levels decreased fresh and dry weights of leaves, the highest depression was obtained by the treatment 18000 ppm, such depression was statistically significant as compared with other treatments in the $1^{\text {st }}$ and $2^{\text {nd }}$ seasons. These results were confirmed by Sahoo et al (2005) who stated that, dry matter of marigold (Tagetes erecta) was decreased significantly with high salinity levels $(\mathrm{NaCl})$, also results here were supported by Ece and Atilla (2007) on strawberry and Ahmed (2008) on wheat, Rahman et al (2008) on Oryza sativa, Cha-Um and Kirdmanee (2009) and Emine et al (2010) on Zea mays and Amirjani (2010) on soybean they reported that increasing of salinity $6-100 \mathrm{ds} / \mathrm{m}^{2}$ reduced fresh and dry weights of shoots and roots.

In regard to the effect of potassium on fresh and dry weights of leaves under salinity conditions, results presented in the same Tables (3 and 4) indicated that the studied treatments of potassium mitigated the harmful effects of different levels of salinity $\left(\mathrm{NaCl}+\mathrm{CaCl}_{2}\right)$. In this respect level 3000 ppm gave the highest significant result 8.5 and 9.3 for fresh weight and $3.7 \mathrm{~g}$ and 4.1 for dry weight respectively for $1^{\text {st }}$ and $2^{\text {nd }}$ seasons, compared to control treatment. Most significant interaction was obtained by the treatment $3000 \mathrm{ppm}$ potassium with the level $14000 \mathrm{ppm}$ of salinity ( 8.8 and 9.5 for fresh weight, and 3.9 and $4.2 \mathrm{~g}$ for dry weight, respectively for tow seasons). Similar results were obtained by Yagmur et al (2007) where they proved that potassium application had positive effects on salinity and alleviated the negative effects of salinity.
Fig. (1 and 5) showed that the proline content in leaves was gradually increasing with rising salinity treatments. The treatment $18000 \mathrm{ppm}$ had high increases of proline content ( 3.4 and $4.3 \mathrm{mg} / \mathrm{g}$ ), compared to control treatment which recorded the lowest values $\left(0.5\right.$ and $0.7 \mathrm{mg} / \mathrm{g}$ in the $1^{\text {st }}$ and $2^{\text {nd }}$ seasons, respectively). In this respect Cardenas et al (2006) on Phaseolus vulgaris L. showed that, the higher free proline content was found with (0.10 and $150 \mathrm{mM} \mathrm{NaCl}$ ), Arunothai and Hans (2008) on Salvinia natans, Najad et al (2008) on Pisum sativum L, Sakr and Arafa (2009) on Canola plants (Brassica nupus), reported that proline accumulation in the presence of salt stress is a good indicator of stress perception. Higher proline content alleviated the negative effects germinated by salinity, allowing an adequate water economy and protecting photosynthetic tissues Franco and Veliz (2007). In addition Ashraf and Foolad (2007) and Plaza et al (2009) on Cordyline fruticosa, noticed that proline is a more major organic osmolyte that accumulated in a variety of plant species in response to environmental stress such as drought and salinity.

\section{$\mathrm{Na}, \mathrm{Ca}$ and $\mathrm{K}^{+}$contents}

Figs. (2, 3, 4, 6, 7 and 8) revealed that the leaves content of $\mathrm{Na}, \mathrm{Ca}$ and $\mathrm{K}$ had the same tendency, which increasing with progressively raising of salinity levels. High levels of salinity 18000 ppm had a marked significant increase of each of these minerals content compared to the control treatment which recorded the lowest values for these minerals, in the $1^{\text {st }}$ and $2^{\text {nd }}$ seasons under study. These results were in agreement with Prado et al (2006) who stated that, $\mathrm{K}+$ is an essential macronutrient and the most abundant inorganic cation in plant cells, whereas $\mathrm{Na}+$ toxicity is a principal component of the deleterious effects associated with salinity stress, Similar results were obtained by Silveira et al (2009) on Atriplex nummularia, and Tsialtas et al (2010) on Beta vulgaris, Genhua et al (2010) on Rosa rootstock, they revealed that, $\mathrm{Na}$ and $\mathrm{K}$ were increased with increasing salinity and stated that, $\mathrm{Na}$ : $\mathrm{K}$ ratio in older leaves appears to be a useful marker for salinity tolerance.

Regarding the effect of potassium on leaf content of potassium under salinity conditions, results presented in the same Tables indicated that the studied treatments of potassium significantly increased the leaf content of potassium. In this

\section{Proline content}




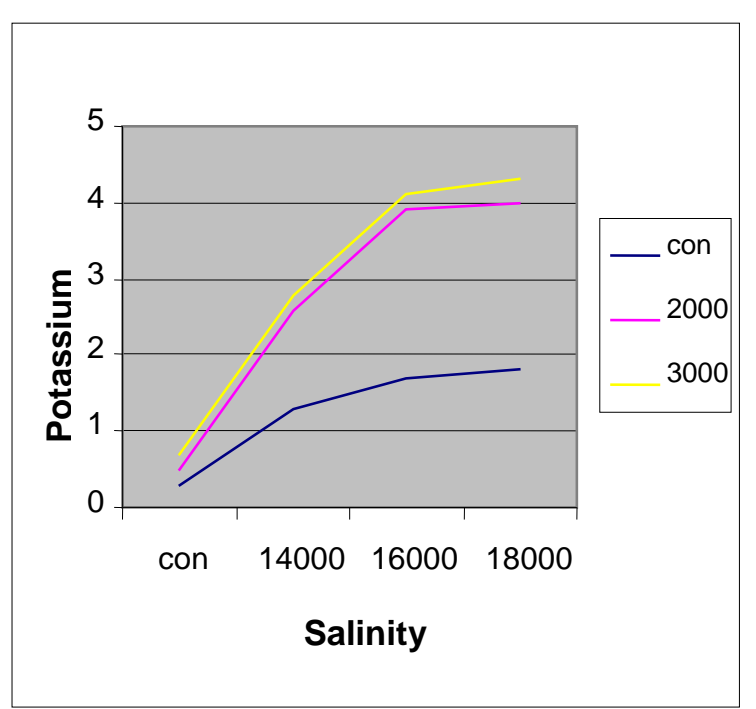

Fig. 1. Effect of potassium and salinity concentrations on proline content of leaves date palm

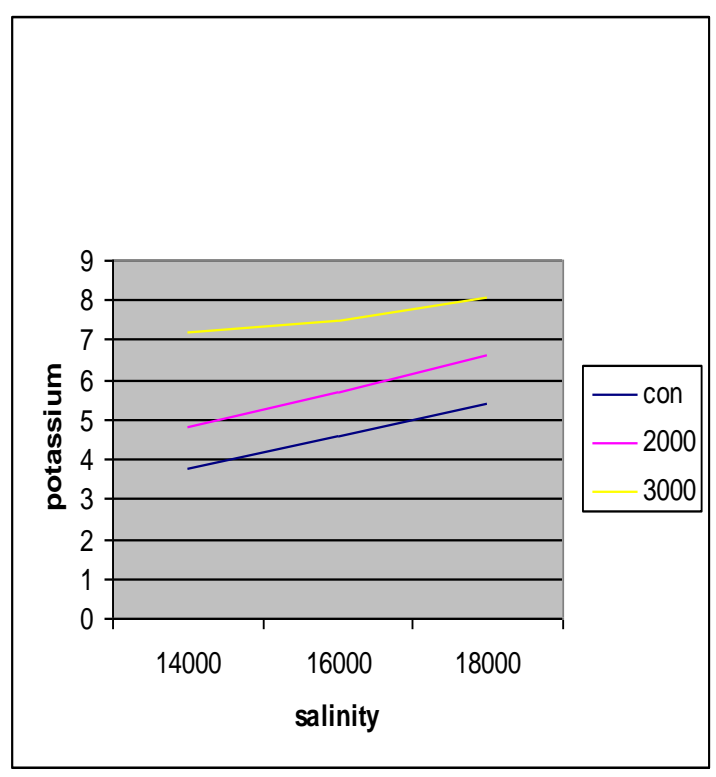

Fig. 3. Effect of potassium and salinity on calcium content of leaves date palm

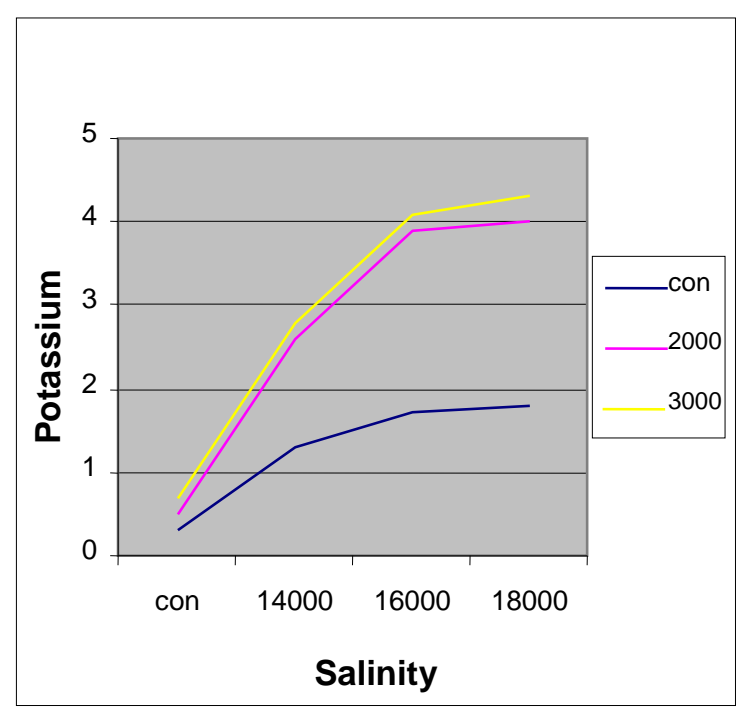

Fig. 2. Effect of potassium and salinity concentrations on leaves sodium contents of date palm

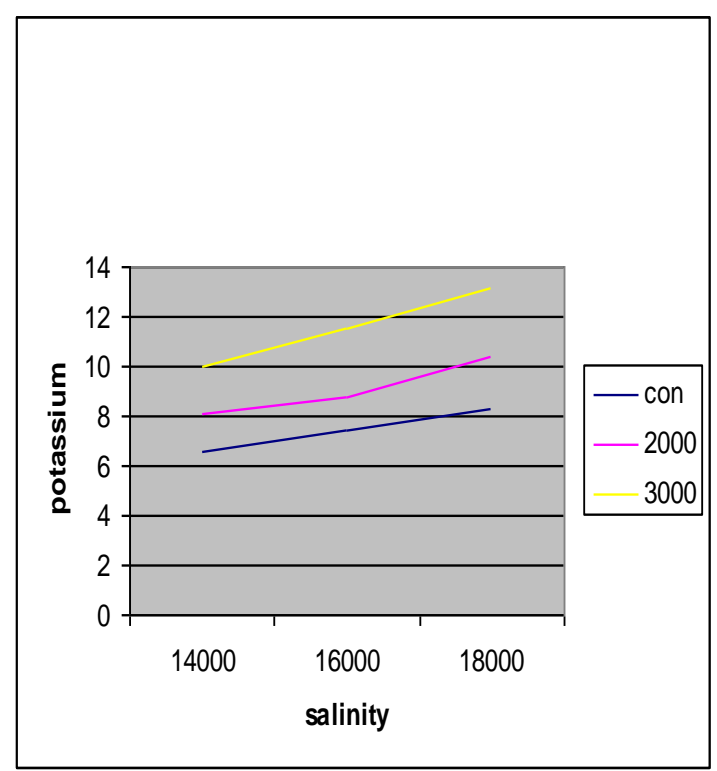

Fig. 4. Effect of potassium and salinity on content potassium of leaves date palm

Effect of potassium and salinity concentrations on proline $\mathrm{mg} / \mathrm{g}$, sodium, calcium and potassium (ppm d.w.) contents of leaves date palm at the first season 


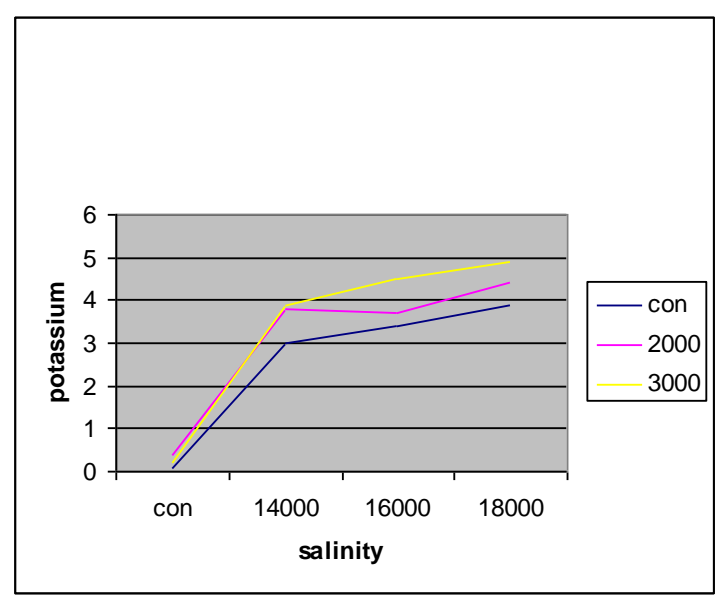

Fig. 5. Effect of potassium and salinity on proline content of leaves date palm

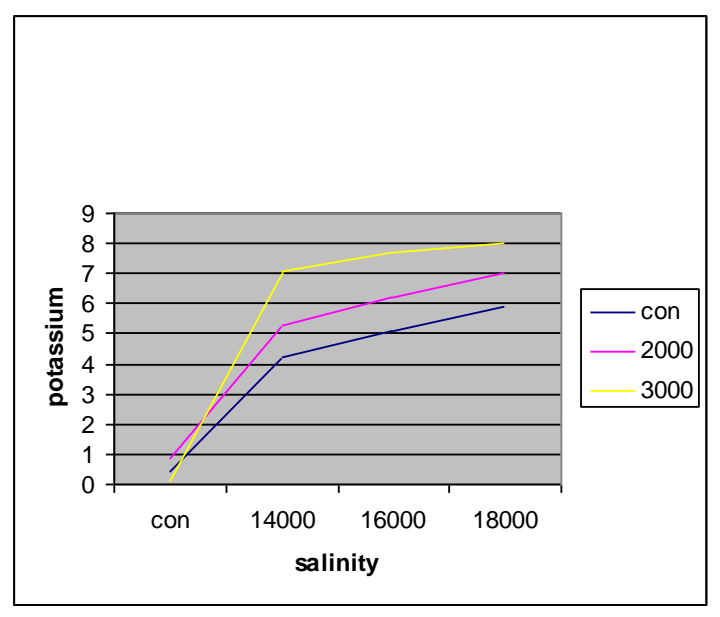

Fig. 7. Effect of potassium and salinity concentrations on content of calcium of leaves date palm

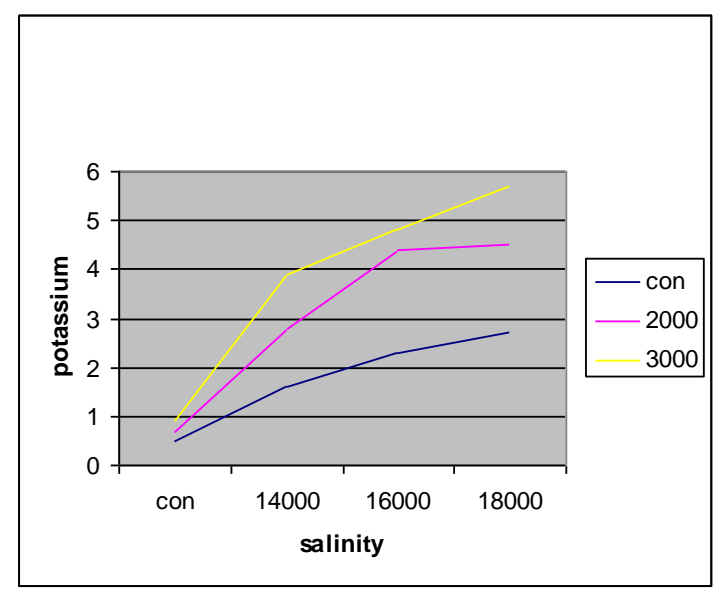

Fig. 6. Effect potassium and salinity on content of sodium ( $\mathrm{mg} / \mathrm{g} \mathrm{d.w}$ ) of leaves date palm

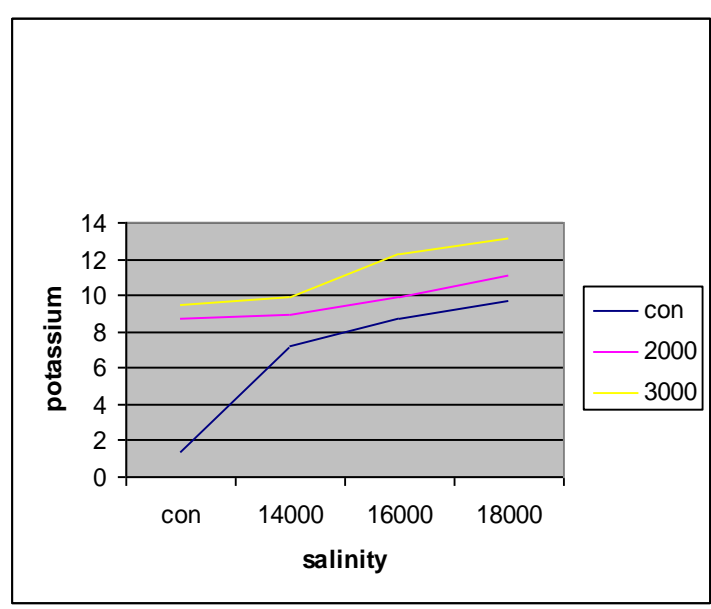

Fig. 8. Effect of potassium and salinity concentrations on potassium content of leaves date palm

Effect of potassium and salinity concentrations on contents of proline ( $\mathrm{mg} / \mathrm{g} \mathrm{d.w.),} \mathrm{sodium,} \mathrm{calcium}$ and potassium (ppm d.w.) of leaves date palm at the second season

respect level 3000 ppm gave the highest significant result. Most significant interaction was obtained by the treatment 3000 ppm potassium with the level 18000 ppm of salinity. Soad (2005) on jojoba (Simmondsia chinensis), Bahmaniar et al (2006) on Triticum aesitivum L, Mahmoud and Athar (2008) on Panicum turgidum revealed that, $\mathrm{Na}$ and $\mathrm{K}$ were increased with increasing salinity (1.5- $6.0 \mathrm{ds} / \mathrm{m}$ ) and stated that, $\mathrm{Na}: \mathrm{K}$ ratio in older leaves appears to be a useful marker for salinity tolerance. The relative tolerance to salinity appeared to be due primarily to their ability to exclude $\mathrm{Na}$ from leaves.

From the obtained results it can be concluded that the plantlets of date palm which were produced by tissue culture can be tolerant to salt stress by addition of potassium which has high significant mitigation effects on the growth parameters of plantlets. 


\section{REFERENCES}

Abdou, A.A.; A.S.A.A. El Hamd and M.E. Ahmed (2006). Effect of irrigation with saline water on growth and yield of sweet fennel. Annals of Agricultural Science, Moshtohor, 44(1): 265-277.

Ahmed, M. (2008). Effects of salinity and PH on gas exchange and growth of wheat under hydroponic conditions. Pakistan Journal of Biological Science, 3(4): 644-646.

Al-Hamdani, S.H. (2008). Influence of various $\mathrm{NaCl}$ concentration on selected physiological responses of kudzu. Asian Journal of Plants Science, 3(1): 114-119.

Al-Mansoori, T.A.; M.N.A. El-Deen and P.D.S. Caligarin (2007): Evaluation of in vitro screening techniques for salt tolerance in date palm. Acta Horticulture, 736: 301-307.

Amirjani, M.R. (2010). Effect of salinity stress on growth, mineral composition, proline content. Plant Physiology, 5: 350-360.

Arunothai, J. and B. Hans (2008). Effects of $\mathrm{NaCl}$ salinity on growth, morphology, photosynthesis and praline accumulation of Salvia natans. Aquatic Botany, 91(3): 181-186.

Ashraf, M.; N. Mukhtar; S. Rehman and E.S. Rha (2004). Salt induced changes in photosynthetic activity and growth in a potential plant bishops weed (Ammolei majus L.). Photosynthetica, 42: 543-550.

Ashraf, M. and M.R. Foolad (2007). Roles of glycine betaine and proline in improving plan abiotic stress resistance. Environmental and Experimental Botany, 59(2): 206-216.

Azza, A.M.M.; M.Z. Sahar and A.A. Yassen (2006). Response of Dalbergia sisso to sulphur application under saline condition. American Eurasian Journal of Agriculture and Environ.Sci. 1 (3): 215-224.

Badr, N.M.; A.T. Thalooth and M.M. Tawfik (2005). Effect of different patterns of potassium fertilization on growth and yield of canola (Brassica napus L.) grown under different levels of saline irrigation. Bulletin of the National Research Centre Cairo, 30(5): 507-520.

Bahmaniar, M.A. (2006). The interactive effects of saline irrigation under potassium and gypsum on mineral nutrient accumulation and (grain protein content of wheat Triticum aestivium L.). Journal of Agronomy, 5(2): 257-261.

Bates, L.S.; R.P. Waldern and I.D. Tear (1973). Rapid determination of free proline under water stress studies. Plants and Soil, 39:205-207.

Bajehbaj, A.A. (2010). The effect of $\mathrm{NaCl}$ priming on salt tolerance in sunflower germination and seedlings grown under salinity conditions. African Journal of Biotechnology, 9(12): 1764-1770.

Bhadauria, H.S. and V.Kumar (2008). Effect of mulching on growth and productivity of okra (Abelmoschus esculentus L.) moench under saline irrigation condition. American Journal of Plant Physiology, 1(2): 214-216.

Bondok, A.; H. Tawfic; A. Shaltout and N. Abdel-Hamid (1995). Effect of salt stress, growth and chemical constituents of three peach rootstocks. Assiut Journal of Agriculture Science, 26:173-194.

Cardenas, A.M.L.; S.J. Verde; R.K. Maiti; P.R. Foroughbaknch; G.H. Gamez; L.S. Martinez; G.M.A. Nunez; D.O. Garcia; P.J. Hernandez; L. and V.M.R. Morales (2006). Variability in accumulation of free proline on in vitro calli of four bean (Phaseolus vulgaris L.) varieties exposed to salinity and induced moisture stress. Phyton Buenos Aires, 75: 103108.

Castro, V.M.; R.E. Iturrieta and C.O. Fassio (2008). Rootstock effect on the tolerance of cv. Hass avocado plants to $\mathrm{NaCl}$ stress. Chilean Journal of Agricultural Research, 69 (3):316-324.

Cha-Um, S. and C. Kirdmanee (2009). Effect of salt stress on proline accumulation, photosynthetic ability and growth characters in two maize cultivars. Park Journal Bot., 41(1): 8798.

Dashtakian, K. and M.J. Bahrani (2007). Effect of various salinity sources and levels on growth and solute composition of madder (Rubia tinctoria). Agricultural Science, Tabriz, 17: 6368.

Delgado, I.C. and R.A.J. Sanchez (2007). Effect of sodium chloride and mineral nutrients and initial stages of development on sunflower life. Communications in Soil Sciences and Plant Analysis, 38(15/16): 2013-2027.

Ece, T. and E. Atilla (2007). Growth and stomatal behaviour of two Strawberry cultivars under long term salinity stress. Turk Journal Agriculture, 31:55-61.

El-Araby, M.M.; A.H. Nassar and H.F. Shaaban (2008). A possible role of triosephosphate/phosphate translocator of chloroplast, envelope membrane in the response 
of Tomato plants to salinity. International Journal of Botany. 2(2): 177-186.

El-Tantawy, A.A.; A.M.S. Arafa; A.E. El-Banna and R.S.S. Darwesh (2006). Effect of Salts Stress on Growth and Development in Vitro culture, Acclimatization Stage on Phoenix dactylifera L. and Arecastrum romanzoffianum Becc. Seedlings in Greenhouse, pp. 55. Ph.D. Thesis, Faculty of Agriculture, Cairo Univ. Egypt.

Emine,B.C.; C.Necmettin ; B.Gamze and B.A. Bulent (2010). The effects of salt stress on the growth, biochemical parameters and mineral element content of some maize (Zea mays L.) cultivar. African Journal of Biotechnology, 9(41): 6937-6942.

Franco, S.V.A. and J.A. Veliz (2007). Responses of the cactus pear (opuntia Ficus indica L.) to $\mathrm{NaCl}$. Interciencia, 32(2): 125-130.

Genhua, N.; S.R. Denise and A. Lissie (2010). Effect of saline water irrigation on growth and physiological responses of three Rose rootstocks. Hortscience, 43 (5): 1479.

Gherroucha, H.; M.Baka and S.A. Moharid (2003). Effect of foliar application with indole acetic acid and gibberellic acid and interaction between them on growth and some physiological constituents of wheat plant grown under salinity conditions. Arab Universities Journal of Agriculture Sciences, Cairo, 11(1): 69-85.

Hokmabadi, H.; K. Arzani and P.F. Grierson (2005). Growth, chemical composition and carbon isotope discrimination of pistachio (Pistacia vera L.) rootstock seedlings in response to salinity. Australian Journal of Agricultural Research, 56: 135-144.

Jackson, M.L.(1973). Soil Chemical Analysis. Printica-Hall of India, Private Limited, New Delhi.

Jampeetong, A. and H.Brix (2009). Effect of $\mathrm{NaCl}$ salinity on growth, morphology,photosynthesis and proline accumulation of Salvinia natans. Aquatic Botany, 91(3): 181-186.

Kapoor, K. and A. Srivastava (2010).Assessment of salinity tolerance of Vigna mungo var pu-19 using ex vitro and in vitro method. Asian Journal Biotechnology, 2: 73-85.

Kathiresan, K. and N. Rajendran (2008). Growth of mangarove (Rhizophora apiculata) seedlings as influenced by GA3, light and salinity. Revista de Biologia Tropical, 50 (2): 34-44.

Kaya, C.; A.L. Tuna; A. Muhammad and H. Altunlu (2007). Improved salt tolerance of melon (Cucumis melo L.) by the addition of praline and potassium nitrate. Environmental and Experimental Botany, 60 (3):397-403.

Khalid, M.N.; H.F. Iqbal; A. Tahir and A.W.N. Ahmed (2008). Germination potential of chick peas (Cicer arietinum L.) under saline conditions. Pakistan Journal of Biological Sciences, 4(4): 395-396.

Kulkarni, T.S.; U.T. Desai; D.B. Kshirsagar and A.B. Kamble (2007). Effects of salts regimes on growth and mineral uptake of pomegranate (Punica granatum L.) cv. Mrudula. Annals of Arid zone, 46(1): 77-82.

Mahdavi, B. and S.A.M.M. Sanavy (2007). Germination and seedling growth in grass pea (Lathyrus sativus) cultivars under salinity conditions. Pakistan Journal of Biological Science, 10(2): 273- 279.

Mahmoud, S. and H.U.R. Athar (2008). Germination and growth of Panicum turgidum provenance under saline conditions. Pakistan Journal of Biological Sciences, 6(2): 164166.

Malakouti, M.J. (2006). Increasing the yield and quality of pistachio nuts by applying balanced amounts of fertilizers. Acta Horticulturae, 726: 293- 300.

Mickelbart, M.V.; S. Melser and M.L. Arpaia (2007). Salinity induced changes in ion concentrations of (hass) avocado trees on three root stocks. Journal of Plant Nutrition, 30(13): 105- 122.

Muhammad, Z. and F. Hussain (2010). Vegetative growth performance of five medicinal plants under $\mathrm{NaCl}$ salt stress. Park Journal Botany, 42(1): 303-316.

Musyimi, D.M.; G.W. Netonodo and G. Ouma (2008). Effect of salinity on gas exchange and nutrients uptake in avocados. Journal of Biological Science, 7(3): 495-505.

Naeem, J.; M.Y. Ashraf; J. Farrukh; V. Martinez and K. Ahmed (2006). Nitrate reduction and nutrient accumulation in wheat grown in soil salinized with four different salts. Journal of Plant Nutrition, 29(3): 409-421.

Najad, K.R.A.; F. Najafi; R.F. Jazil and M. StickIen (2008). Physiological changes in pea ( $\mathrm{Pi}-$ sum sativum L.) Cv. Green Arrow under $\mathrm{NaCl}$ salinity. Pakistan Journal of Biological Sciences, 9(5): 974-978.

Plaza, B.M.; S. Jimenez; M.L. Segura; J.I. Contreras and M.T. Lao (2009). Physiological stress caused by salinity in Cordyline fruticosa and its indicators. Soil Science and Plant Analysis, 40(1-6): 473-484. 
Prado, J.M.; B. Cubero; E.O. Leidi; and F.J. Quintero (2006). Alkali cation exchangers: roles in celluar homeostasis and stress tolerance. Journal of Experimental Botany, 57 (5): 1181-1199.

Prakash, R.P.; S.K. Sushil; R.P. Vinary; J.P. Vimal and M.K. Sunil (2010). Impact of saline water stress on nutrient uptake and growth of Cowpea. Brazilian Journal of Plant Physiology, 22(1): 43-48.

Rahman, M.S.; H. Miyake and Y. Takeoka (2008). Effect of sodium chloride salinity on seed germination and early seedling growth of rice (Oryza sativa L.). Pakistan Journal of Biological Sciences, 4(3): 351-355.

Sahoo, S.S.; S.K. Sharma; A.S. Nandwal; A.K. Kapoor; N. Kumar; S.S. Dahiya and S. Kukreja (2005). Phosphorus nutrition influences plant water status, mineral distribution, dry matter and yield of marigold under saline environments. Journal of Plant Biology, 32(3):189-198.

Sakr, M.T. and A.A. Arafa (2009). Effect of some antioxidants on canola plants (Brassica napus) grown under soil salt stress conditions. Pak. Journal Biology Science, 12: 582-588.

Sannazzaro, A.I.; M. Echeverria; E.O. Alberto; O.A. Ruiz and A.B. Menendez (2007). Modulation of polyamine balance in Lotus glaber by salinity and arbuscular mycorrhiza. Plant Physiology and Biochemistry, 45(1): 39- 46.

Seema, A.H. and N.P. Amar (2008). Growth water status and nutrient accumulation of seedlings of Acacia Senegal L. willd in response to soil salinity. Anales de Biologia, 30: 17-28.

Shibli, R.A.; M.A. Shatnawi and I.Q. Swaidat (2003). Growth, osmotic adjustment, and nutrient acquisition of better almond under induced sodium chloride salinity in vitro. Communications in Soil Science and Plant Analysis, 34 (13/14):1969-1979.

Shirazi, M.U.; M.Y Ashraf; M.A. Khan and M.H. Nqvi (2005). Potassium induced salinity tolerance in wheat (Triticum aestivum L.). International Journal of Environmental Science and Technology, 2(3): 233-236.

Silveira, J.A.G.; S.A.M. Araujo; J.P.M.S. Lima and R.A. Viegas (2009). Roots and leaves display contrasting to $\mathrm{NaCl}$ salinity in Atriplex nummularia. Environmental and Experimental Botany, 66(1): 1-8.

Snedecor, G.W. and W.G. Cochran (1980). Statistical Methods. Seventh Edition, lowa State Univ., Press, Ames, lowa, U.S.A.

Soad, M.M. (2005). Response of Vegetative Growth and Chemical Composition of Jojoba Seedling (Simmondsia chinensis) to Some Agriculture Treatments. p. 80. Ph.D. Thesis, Fac. of Agric. Minia Univ., Egypt.

Sorial, M.E.; M.A. Mansour; H.A. Wahdan; A.M. Maria and S.A. Hammad (2001). Effect of nitrogen fertilization under salinity conditions on some growth, physiological, chemical and anatomical characteristics of peppermint. Annals Agricultural Science Moshtohor, 39(4): 2021-2043.

Sotiropoulos, T.E.; I.N. Therios; V. Tsirakoglou and K.N. Dimassi (2006). Response of the quince genotypes BA2g and EMA used as pear rootstocks to boron and salinity. International Journal of Fruit Science, 6(4): 93-101.

Subbarao, G.V.; O. Ito; W.L. Berry and R.M. Wheeler (2003). Sodium- A functional plant nutrient. Plant Science, 22: 391-416.

Tsialtas, J.T. and N. Maslaris (2006). Leaf carbon isotope discrimination relationships to element content in soil, root and leaves of sugar beets grown under Mediternean conditions. Field Crop Research, 99: 125-135.

Tsialtas, J.T.; T. Matsi and N. Maslaris (2010). Plasticity of leaf anatomy, chemistry and water economy of irrigated sugar beets grown under Mediternean conditions. International Journal of Plant Production, 4(2): 99-114.

Wan, J.; L. Shi; J. Zhang and G. Tang (2006). Effect of salt stress on some physiological indexes in Iris leaves. Journal of Nanjing Forestry University Natural Science Edition, 30(1): 57-60.

Yagmur, M.; D. Kaydan and N. Okut (2007). Alleviation of salinity stress during seed germination in wheat (Triticum aestivum) by potassium applications. Indian Journal of Agricultural Science, 77(6): 379-382.

Zaki, M.F.; S.D. Abou-Hussein; M.M. Abou ElMagd and H.M.H. El-Abagy (2009). Evaluation of some sweet fennel cultivars under saline irrigation water. European Journal of Scientific Research, 30(1): 67-78. 